\title{
Examining dual accounting systems in Europe
}

\author{
Marta Macías *, Flora Muiño \\ Department of Business Administration, Universidad Carlos III de Madrid, Calle Madrid, 126, 28903 Getafe, \\ Madrid, Spain
}

\begin{abstract}
After adoption of International Financial Reporting Standards (IFRS) for consolidated financial statements by European listed companies, a number of European countries still require the use of local standards in the preparation of legal entity financial statements. This study investigates whether this requirement can be explained by a low demand for high quality financial reporting and an orientation of accounting toward the fulfilment of regulatory needs in these countries. Specifically, using accounting quality as an indicator of the focus of accounting on capital providers' needs, we compare accounting quality between countries permitting and prohibiting the use of IFRS in individual financial statements. Consistent with our expectations, we find that countries requiring the use of local standards in the preparation of legal entity financial statements exhibit a significantly lower level of accounting quality, both prior to and after IFRS adoption. We interpret these results as evidence that these countries have local standards more oriented toward the satisfaction of regulatory needs, rather than investors' needs. Furthermore, since differences in accounting quality persist after the implementation of IFRS, results suggest that firms in these countries face a lower demand for high quality financial reporting.
\end{abstract}

Keywords: IFRS endorsement; Accounting quality; Value relevance; Domestic GAAP

We appreciate the financial support from the Spanish Ministry of Education through grants SEJ 2007 and SEJ2010, and the Comunidad de Madrid through grant CCG06-UC·M/TIC-0766. We thank the editor and two anonymous referees for their valuable comments and suggestions. In addition, we are especially grateful to one of the referees for help in editing this manuscript. The paper also benefited from comments of the participants at the 2008 annual EAA Congress in Rotterdam. All remaining errors are our responsibility only.

* Corresponding author. Tel.: +34916249370.

E-mail address: marta.macias@uc3m.es (M. Macías). 


\section{Introduction}

Diversity in accounting practices has been shown to deter cross-country investment decisions due to the increase in information asymmetries and information costs it entails (e.g., Ahearne, Griever, \& Warnock, 2004). Accordingly, harmonization of accounting practices is assumed to reduce barriers to cross-country investments (e.g., Bradshaw, Bushee, \& Miller, 2004). Convergence of accounting standards is expected to improve confidence in publicly traded companies, fostering the development of capital markets and thereby promoting economic growth (Hope, Justin, \& Kang, 2006). With this aim, in the last decade of the 20th century, the European Union (EU, hereafter) established a new strategy regarding accounting harmonization that crystallized in the requirement of European-listed companies to prepare, since 2005, their consolidated accounts in accordance with International Financial Reporting Standards (IFRS) ${ }^{1}$ (Regulation EC 1606/2002).

The mandatory adoption of IFRS in the EU represents one of the largest regulatory experiments ever undertaken (Christensen, Lee, \& Walker, 2007). It is based on the assumption that accounting harmonization is a necessary requirement for the globalization of capital markets, as it improves comparability of financial statements. ${ }^{2}$ This new regulation has affected approximately 7000 EU-listed companies (CESR, 2007). Regarding legal entity financial statements, however, Regulation EC 1606/2002 allows European Member States to either allow or require companies to follow domestic standards. This is particularly striking, as the European Commission expressed in 1995 (COM 95 (508): 4) that:

"3.3. [T] he most urgent problem is that concerning European companies with an international vocation. The accounts prepared by those companies in accordance with their national legislation, based on the Accounting Directives, are no longer acceptable for international capital market purposes. These companies are therefore obliged to prepare two sets of accounts, one set which is in conformity with the Accounting Directives and another set which is required by the international capital markets. This situation is not satisfactory. It is costly and the provision of different figures in different environments is confusing to investors and to the public at large."

In addition to the problems of cost and confusion, the Commission also acknowledged that the coexistence of different reporting frameworks deters effective supervision and enforcement of financial reporting requirements of publicly traded companies. This, in turn, harms investors' confidence in listed firms, thus hampering cross-border trade and putting EU securities markets globally at a severe competitive disadvantage.

\footnotetext{
${ }^{1}$ For purposes of simplicity, we use the term IFRS to refer both to the IFRS issued by the International Accounting Standards Board (IASB) and the International Accounting Standards (IAS) issued by its predecessor, the International Accounting Standards Committee (IASC).

${ }^{2}$ Barth, Landsman, Lang, and Williams (2009) document an increase in comparability between U.S.-GAAPbased and IFRS-based accounting amounts following IFRS adoption, especially after 2005. The importance of harmonization for international valuation and allocation of resources is highlighted in the study by GómezBiscarri and López-Espinosa (2008). They show that, at the international level, the Fama and French (1993) threefactor model performs significantly better when using homogeneous information (i.e., IFRS accounting measures).
} 
Table 1

Sample companies.

\begin{tabular}{lccl}
\hline Country & Number of companies & \% over total sample & IFRS permitted in all company statements \\
\hline Denmark & 47 & 4.52 & Yes $^{\text {a }}$ \\
Finland & 63 & 6.06 & Yes \\
Greece & 52 & 5.01 & Yes \\
Ireland & 0 & 0 & Yes \\
Luxembourg & 3 & 0.29 & Yes \\
Netherlands & 59 & 5.68 & Yes \\
Norway & 56 & 5.39 & Yes \\
United Kingdom & 86 & 8.28 & Yes \\
Austria & 7 & 0.67 & No \\
Belgium & 28 & 2.7 & No \\
France & 222 & 21.36 & No \\
Germany & 88 & 8.47 & No \\
Italy & 142 & 13.67 & No \\
Portugal & 12 & 1.16 & No \\
Spain & 70 & 6.74 & No \\
Sweden & 104 & 10.01 & No \\
Total & 1039 & 100 & \\
\hline
\end{tabular}

a Yes indicates that firms in this country are allowed to use IFRS in all company statements. These countries are named full adopters in the present study.

b No indicates that firms are required to apply local standards in legal entity financial statements. These countries are named partial adopters in the present study.

$\uparrow$ Although Germany permits the use of IFRS in legal entity financial statements, statutory accounts that conform to national GAAP are also required. This is why this country is classified as a partial adopter country.

In spite of the views expressed by the European Commission, about half of the Member States forming the EU at the time Regulation EC 1606/2002 was passed opted for requiring the application of local standards in the preparation of legal entity statements ${ }^{3}$ (see Table 1). In this study, we name them partial adopters, since two accounting systems still coexist in these countries: consolidated financial statements are prepared in accordance with IFRS, while legal entity financial statements follow domestic standards. ${ }^{4}$ The rest of countries (full adopters, hereafter) permit the use of IFRS in all company statements.

This study investigates whether the decision to retain local standards for legal entity financial statements in EU Member States is associated with differences in the roles played by accounting information and, as a consequence, with dissimilarities in the demand for highquality financial reporting across European countries. We argue that countries in which the

\footnotetext{
${ }^{3}$ In some cases, decisions adopted by Member States regarding individual financial statements vary depending on the type of companies. As an example, Italy permits the use of IFRS in legal entity financial statements, except for insurance companies, small firms, and certain regulated companies. The reader can refer to ICAEW (2007) for a detailed description of the option selected by each country for each type of companies. In this study, we name full adopters those countries that permit all firms to use IFRS both in legal entity and consolidated financial statements. The rest of the countries (e.g., Italy) are named partial adopters, since these countries require that all companies, or at least certain types, apply local standards in the preparation of legal entity financial statements.

${ }^{4}$ According to the survey by Jermakowicz and Gornik-Tomaszewski (2006), European companies perceive that the expected benefits of IFRS adoption may not occur if subsidiaries are required to apply local GAAP in preparing their individual financial statements.
} 
preservation of the regulatory function traditionally played by accounting is important have retained local standards for legal entities because IFRS, due to its focus on the information needs of capital providers (Whittington, 2005), will not fulfill this requirement. ${ }^{5}$

As an indicator of the orientation of the accounting system toward the needs of capital providers, we use accounting quality, measured in this study as the explanatory power of accounting measures for stock prices and one-year-ahead operating cash flows. ${ }^{6}$ Both measures of accounting quality reflect the usefulness of accounting information for investors and creditors. Hence, we assume that higher levels of accounting quality are indicative of the orientation of accounting toward the satisfaction of capital providers' needs, whereas lower levels of financial reporting quality indicate that accounting is fulfilling other roles.

To carry out our analyses, we exploit the advantage of the information prepared for the first-adoption of IFRS in Europe. European-listed companies starting to apply IFRS in 2005 were required to restate their prior-year (2004) financial statements to IFRS. As a result, two sets of financial statements are available for 2004: (1) those prepared in accordance with local accounting standards and included in the 2004 annual report and (2) those restated to IFRS and released jointly with the 2005 financial statements. This allows us to compare accounting numbers prepared under IFRS and domestic standards for the same set of companies and the same year. This approach ensures that differences observed between financial measures are exclusively due to differences in accounting standards, since everything else is held constant. It also eliminates the problem of controlling for the change in the firms' incentives to improve financial reporting faced by researchers in previous studies (e.g., Barth, Landsman, \& Lang, 2008). In our design, identical economic reality is recorded by firms using two different sets of accounting standards. Moreover, the fact that our analyses refer to the same time period (2004) ensures that differences observed in the explanatory power of accounting measures are not due to changes in the economic environment. Hence, firm, country, or even economic factors that might affect corporate accounting quality are held constant in our study.

Using a sample of European non-financial companies we show that, before the application of IFRS, our measures of accounting quality (i.e., the explanatory power of earnings and equity book value for stock prices and the ability of earnings to explain future cash flows) are significantly higher for firms in the group of full adopters. These results are consistent with the argument that companies in these countries face a stronger demand for high-quality information and that local accounting standards were already designed to cover this demand.

IFRS adoption decreases (increases) the explanatory power of earnings and equity book value for stock prices in the group of full (partial) adopters, although differences are not statistically significant. With regard to the ability of earnings to explain future cash flows, it

\footnotetext{
${ }^{5}$ As an example, accounting serves taxation purposes in a number of European countries (e.g., Germany and France), and with this aim domestic accounting standards are heavily aligned with taxation rules. Such an alignment is not observed for IFRS. As a consequence, IFRS are not able to fulfill the same role in computing income taxes as that played by domestic standards. For further discussion, see Nobes (1998).

${ }^{6}$ The explanatory power of accounting figures for stock prices is widely used by researchers as an indicator of accounting quality (e.g., Barth et al., 2008; Bartov, Goldberg, \& Kim, 2005; Lang, Raedy, \& Wilson, 2006). We complement it with the ability of accounting measures to explain one-year-ahead operating cash flows. Even though stock prices are expected to reflect the stream of future cash flows, this is a more direct test of the ability of accounting measures to predict cash flows (Al-Attar \& Hussain, 2004; Barth, Cram, \& Nelson, 2001).
} 
significantly increases in both groups of countries. ${ }^{7}$ Furthermore, we observe that changes in accounting quality are larger in the group of partial adopters. Taken together, results for stock prices and future cash flows provide weak evidence of an increase in accounting quality after IFRS adoption. However, what is clearly shown is that the effect of IFRS implementation on accounting quality is different for firms in the group of full and partial adopters. Hence, results suggest that full and partial adopter countries differ in the primary aim of their domestic standards.

Finally, we observe that, despite the changes motivated by IFRS adoption, accounting quality is still significantly lower in countries prohibiting the use of IFRS in legal entity financial statements. We interpret these results as further evidence that the demand for highquality financial reporting is lower in this group of countries.

Overall, this study provides evidence consistent with the hypothesis that firms in countries that retained the use of local standards in legal entity financial statements face a lower demand for high-quality financial reporting. Results suggest that, rather than the information requirements of capital providers, local standards in these countries satisfy other needs (e.g., regulatory needs, such as the computation of income taxes). Since IFRS are primarily aimed at fulfilling the information demands of investors and creditors, countries wishing to maintain the regulatory role played by accounting opted for requiring the application of their local standards in the preparation of legal entity financial statements.

Additionally, this study contributes to prior research by providing evidence of the differences in accounting quality between European countries that still existed in 2004, in spite of the harmonization efforts carried out inside the European Union over the last decades. Moreover, we show that implementation of IFRS reduces these differences, but it does not completely remove them. Consistent with prior research (e.g., Ball, Robin, \& Wu, 2003), we find that adoption of IFRS by itself is not sufficient to achieve a high level of accounting quality.

The rest of the paper is organized as follows. Section 2 reviews the literature and develops the hypotheses. Section 3 lays out our research design. Section 4 reports the results of our analyses. Finally, the discussion of the results and conclusions are offered in Section 5.

\section{Background and research questions}

\subsection{Accounting quality in Europe prior to IFRS adoption}

Adoption of IFRS in Europe was motivated by the objective of creating a strong internal capital market given the inability of prior regulation (European Directives) to further foster the necessary accounting harmonization. The Fourth Directive, issued in 1978, and the Seventh Directive, issued in 1983, propelled significant changes in company (and accounting) legislation in EU Member States (Thorell \& Whittington, 1994). However, Regulation 1606/2002 recognized that Council Directives could not ensure the high levels of transparency and comparability necessary to build an efficient integrated capital market.

\footnotetext{
${ }^{7}$ It could be argued that the change in accounting quality is motivated, not only by the introduction of IFRS, but also by the efforts to strengthen the enforcement regime taken in the EU at the same time as IFRS adoption. However, as explained previously, we compare local standards and IFRS accounting measures for the same period (2004), and this assures us that everything, except for accounting rules, is constant.
} 
European Directives established minimum reporting requirements and allowable options, but the standard setting process was left to Member States, who were required to enact provisions complying with Directives into national law. As a result, domestic standards varied considerably depending on country-specific characteristics. The study by Bae, Tan, and Welker (2008) provides a clear picture of the differences in accounting standards across European countries. Based on the survey GAAP 2001: A Survey of National Accounting Rules Benchmarked against International Accounting Standards (Nobes, 2001), Bae et al. (2008) identify differences between domestic standards and IFRS on 21 accounting rules for a sample of 49 countries. Regarding European countries, the number of accounting rules that they find to vary with respect to IFRS ranges from just one, in the case of the United Kingdom and Ireland, to 18 for Luxemburg. ${ }^{8}$

Given the orientation of IFRS toward the needs of capital providers, the differences depicted by Bae et al. (2008) suggest that accounting is not primarily aimed at satisfying capital providers' needs across all European countries. Prior research has highlighted the regulatory role played by accounting in Continental European countries, where accounting standards are set by government bodies and are designed to satisfy regulatory needs (Choi \& Mueller, 1992). Furthermore, Ding, Hope, Jeanjean, and Stolowy (2007) document a significant association between countries' domestic accounting standards dissimilarities with respect to IFRS and the importance of their equity markets. Differences are larger in countries with less-developed capital markets, which suggests that the demand for highquality financial reporting is lower in these countries, since banks tend to supply most of the capital needs of business and usually have direct access to company information (Joos \& Lang, 1994). On the contrary, firms in countries with more-developed capital markets get most of their financing from small shareholders, who rely on public information for their decisions, thus propelling a stronger demand for high-quality financial reporting.

We argue that countries' decisions about whether or not to retain local standards for legal entity financial statements reflect differences in the main role played by accounting. We hypothesize that countries that already have accounting systems oriented toward the satisfaction of the information demands of capital providers permit the use of IFRS in all company statements, since IFRS and their local standards fulfill similar roles. On the contrary, countries requiring the use of local standards in legal entity financial statements are likely to be those where legal entity financial statements prepared in accordance with local standards play a significant regulatory role (e.g., in computing income taxes). Since IFRS financial statements cannot play such a role, countries retain their domestic standards for legal entity financial statements. In this way, they also keep control over these standards, usually set by government bodies.

On the basis of prior arguments and evidence, we expect a higher level of accounting quality for firms in the group of full adopter countries than in partial adopters. Hence, we state our first hypothesis as follows:

H1. Prior to IFRS adoption, firms in full adopters have higher accounting quality than firms in partial adopters.

\footnotetext{
${ }^{8}$ Further evidence of differences in accounting standards across countries is provided by Ashbaugh and Pincus (2001), Hung (2001), and Ding, Jeanjean, and Stolowy (2005).
} 


\subsection{Change in accounting quality resulting from the mandatory shift to IFRS}

Regulators expect an improvement in the level of transparency and the quality of financial reporting after mandatory IFRS adoption (Regulation EC 1606/2002). However, as Daske, Hail, Leuz, and Verdi (2008) explain, there are arguments suggesting an improvement in accounting quality because of the high quality of IFRS, but there are also reasons to think that mandatory adoption of IFRS alone is not sufficient to increase the quality of financial reporting.

IFRS are extensively viewed as a set of high-quality accounting standards. The recommendation of the International Organization of Securities Commission (IOSCO, 2000) that IOSCO members permit foreign companies to use IFRS in preparing financial statements for cross-border offerings and listings is an example of the perceived quality of IFRS. Accordingly, except in those countries with local standards of similar quality to IFRS (e.g., the United Kingdom or Ireland), an improvement in accounting quality can be expected after IFRS adoption. Extant research provides evidence supporting this widely held expectation. As an example, a recent study by Barth et al. (2008) analyzing domestic standards and IFRS across 21 countries, shows that, as compared to firms applying domestic standards, those using IFRS exhibit less earnings management, more timely loss recognition, and more value relevant accounting measures. ${ }^{9}$ Likewise, Ashbaugh and Pincus (2001) report a reduction in analysts' forecast errors when IFRS are applied, concluding that this derives from IFRS providing more predictable measures. Along the same line, Daske and Gebhardt (2006) show an increase in disclosure quality under IFRS in Austria, Germany, and Switzerland prior to mandatory adoption in 2005.

When interpreting the results of the above-mentioned studies, however, we must be aware that they refer to voluntary adoption of IFRS, which may result from corporate incentives to increase transparency. Ashbaugh (2001) documents that the decision to report under IFRS is positively related to corporate size, the number of foreign equity markets where the firm's shares are traded, and the additional issuance of equity shares. Similar findings are reported by Gassen and Sellhorn (2006) and Cuijpers and Buijink (2005). Results of these studies suggest that companies voluntarily shifting to IFRS have incentives to improve transparency and the quality of financial reporting (Leuz \& Verrechia, 2000). Moreover, Covrig, Defond, and Hung (2007) show that foreign mutual fund ownership is significantly higher among IFRS adopters. They conclude that a firm's voluntary switch to IFRS is aimed at attracting foreign investors by providing them with both more information and information that is more familiar to them. Since the same incentives are not likely to be found when IFRS adoption is mandatory, results referring to voluntary shifts may not extrapolate to mandatory adoption cases. Christensen, Lee, and Walker (2008) provide evidence consistent with this view. They investigate voluntary and mandatory shifts to IFRS in Germany, where firms were allowed to switch to IFRS prior to 2005. They find that, while voluntary adoption is associated with an increase in accounting quality, such

\footnotetext{
${ }^{9}$ Similar results are reported by Bartov et al. (2005) and Gassen and Sellhorn (2006) for a single country, Germany. Bartov et al. (2005) show that IFRS earnings are more value relevant, and Gassen and Sellhorn (2006) report that IFRS earnings are more persistent and more conditionally conservative. However, for the same country, Hung and Subramanyam (2007) do not find evidence of a significant difference in the value relevance of accounting measures (earnings and equity book value) after adoption of IFRS.
} 
improvement is not observed in the case of mandatory shifts. They conclude that highquality accounting standards like IFRS do not necessarily lead to higher quality accounting, at least when firms do not perceive net benefits from IFRS adoption. That is to say, adoption of IFRS by itself does not necessarily improve financial reporting, and this brings us to the arguments for the absence of an improvement after mandatory IFRS implementation.

The evidence provided by Christensen et al. (2008) is consistent with prior research showing that accounting standards are not the only factor affecting the quality of accounting systems (Pownall \& Schipper, 1999). Under a given set of standards, financial reporting quality is sensitive to the incentives of preparers, which depend on the interplay between market and political forces, such as the demand for high-quality financial reporting, the involvement of governments in the standard-setting process and the enforcement of standards, and taxes or political incentives to reduce the volatility of reported earnings (Ball et al., 2003). By examining accounting quality in Hong Kong, Malaysia, Singapore, and Thailand, Ball et al. (2003) demonstrate that accounting quality is ultimately determined by the economic and political factors that influence managers' and auditors' incentives, rather than by accounting standards per se. Despite the fact that these four countries have highquality accounting standards derived from common law sources, the authors find that financial reporting quality is not higher than under code-law systems.

Further evidence referring specifically to IFRS adoption and stressing the importance of the institutional environment for the quality of financial reporting is provided by Daske et al. (2008). They investigate the capital market effects of mandatory IFRS adoption in 23 countries around the world and find an increase in market liquidity, a decrease in firms' cost of capital, and an increase in equity valuations, but only in countries where firms have incentives to be transparent and where legal enforcement is strong. ${ }^{10}$ Their evidence underlines the importance of firms' reporting incentives and countries' enforcement regimes for the quality of financial reporting.

Although European countries already had relatively strong legal systems, the EU revised and strengthened its enforcement regime along with the adoption of IFRS (Hail \& Leuz, 2007). As a consequence, an improvement in accounting quality could be expected after the introduction of IFRS. Armstrong, Barth, Jagolinzer, and Riedl (2008) and Daske et al. (2008) provide evidence consistent with this expectation. In an events study, Armstrong et al. (2008) examine the European stock market reaction to the likelihood of IFRS adoption in Europe and find a positive (negative) reaction to events that increased (decreased) the likelihood of IFRS introduction. In the same vein, Daske et al. (2008) find that capital market effects of IFRS adoption are stronger in EU countries than in the rest of the countries that mandate the use of IFRS. Furthermore, they show that capital market effects of IFRS

\footnotetext{
${ }^{10}$ Extant research points even to the possibility of a decrease in accounting quality after mandatory application of IFRS. In an exploratory study of earnings management in Australia, France, and the United Kingdom, Jeanjean and Stolowy (2008) observe that their metric of earnings management (i.e., the ratio of small reported profits to small reported losses) does not significantly change after IFRS adoption in Australia and the United Kingdom, but it increases in France. This can be explained by the high level of judgment involved in the application of IFRS as compared to the rules-based French accounting system. Carmona and Trombetta (2008) argue that because of the principles-based nature of IFRS, their application requires accountants and auditors to perform a number of estimations, which sharply contrasts with the mechanical nature of the accounting process in the rules-based systems existing prior to IFRS adoption in a number of European countries.
} 
adoption are larger for firms in countries with domestic standards that are of a lower quality and that differ more from IFRS (Daske et al., 2008). Likewise, Armstrong et al. (2008) observe that the positive market reaction to IFRS adoption is larger for firms with lower levels of information quality prior to IFRS implementation and higher pre-adoption information asymmetry. Based on prior evidence, we expect that the effect of IFRS adoption on accounting quality varies between full and partial adopter countries. Therefore, we state the following hypothesis to be tested in our study:

H2. Adoption of IFRS in Europe leads to an increase in accounting quality, with the effect being larger for firms in the group of partial adopters than for firms in the group of full adopters.

\subsection{Accounting quality after IFRS adoption}

Besides the increase in accounting quality, endorsement of IFRS in Europe is expected to reduce differences between countries, thereby allowing an increase in comparability of accounting information (Pownall \& Schipper, 1999). The level of reduction in differences, however, is difficult to forecast. On the one hand, extant research documents a process of spontaneous harmonization within European "global players." Companies competing in international markets had entered into a process of harmonization since the 1980s (Cañibano \& Mora, 2000; Thorell \& Whittington, 1994) independently of the formal political process. Likewise, Land and Lang (2003) document an increase in comparability over time of accounting data of firms from Australia, Canada, France, Germany, Japan, the United Kingdom, and the United States.

On the other hand, research points out that full convergence in accounting will never be achieved, due to a number of both firm-specific and country-specific factors (Jaafar \& McLeay, 2007). Research reviewed in the prior section highlights that accounting quality depends, not only on accounting standards, but also on firms' incentives to issue high-quality financial statements. Adoption of IFRS in Europe eliminates differences in one of these elements: accounting standards. In the preparation of their consolidated financial statements, Europeanlisted companies apply the same set of accounting standards. However, the same degree of uniformity does not exist regarding countries' institutional frameworks and, as a consequence, regarding firms' incentives to issue high-quality financial reporting. Extant research provides evidence on the differences between European countries in their level of protection of shareholders' rights, liability standards, the strength of the system of legal enforcement, the level of ownership concentration, the degree of financial and tax alignment, or the importance of the equity market (e.g., Hung, 2001; La Porta, Lopez-de-Silanes, \& Shleifer, 2006, La Porta, Lopezde-Silanes, Shleifer, \& Vishny, 1998). Moreover, research documents the key role played by these institutional characteristics in shaping accounting quality (e.g., Ali \& Hwang, 2000; Ball, Kothari, \& Robin, 2000; Burgstahler, Hail, \& Leuz, 2006; Bushman \& Piotroski, 2006).

The importance of firms' incentives for financial reporting quality is documented by Ball and Shivakumar (2005). They compare public and private companies in the United Kingdom and show that, despite the fact that all of them share the same accounting rules, the timely recognition of economic losses is less prevalent in private than in public firms, suggesting that the demand for accounting quality is higher for public companies. In the same way, we do not expect IFRS adoption to completely remove differences in accounting 
quality between European countries. As in the pre-adoption period, we expect firms in the full-adopters group of countries to exhibit a higher level of accounting quality, because of the stronger incentives that companies in these countries have to issue high-quality financial reporting. Thus, we state our third hypothesis in the following way:

H3. After IFRS implementation, accounting quality is still significantly higher for firms in full-adopter countries than in partial-adopter countries.

\section{Sample and data}

To form our sample, we select those European companies that started to apply IFRS in 2005 , following Regulation 1606/2002. We focus our analysis on the 15 countries comprising the EU when the decision to adopt IFRS was made (2002). ${ }^{11}$ To these countries we add Norway, a non-EU country that is member of the European Economic Area and that, as such, also had to adopt IFRS at the same time as the EU. ${ }^{12}$ Companies incorporated in these countries were required by IFRS-1 to restate their prior-year financial statements to IFRS when preparing their first IFRS financial statements (i.e., 2005 financial statements). Accordingly, there are two sets of financial statements for these companies for the 2004 accounting year: (1) those prepared in accordance with their local standards and published in the 2004 annual report and (2) those restated and presented joined to the 2005 financial statements.

To obtain our sample, we used the Standard \& Poor's Global Vantage database and selected those companies applying domestic standards (DS) in 2004 and international standards (IFRS) in 2005. Accounting measures for 2004 in the Global Vantage database are those originally reported by companies and conforming to local standards. However, the OSIRIS database reports the restated figures to IFRS for 2004. We exploit this advantage and use both databases jointly; we take 2004 accounting measures resulting from the application of local standards from Global Vantage and the 2004 restated figures to IFRS from OSIRIS. The rest of the data needed in our analyses comes from the Global Vantage database.

In the screening process, we delete all companies with missing values on the variables used in our analyses (i.e., net income before extraordinary items and book value of equity for 2004, as reported in 2004 annual reports and restated to IFRS; operating cash flow for 2005; and market value of equity for 2004). To minimize the effect of outliers, we also delete the top and bottom $1 \%$ of the distribution of the variables used in our analyses, as well as observations whose studentized residuals are four or greater in our regression models. The final sample is comprised of 1039 observations from 15 countries ${ }^{13}$ (companies from Ireland did not satisfy the screening criteria). Table 1 presents the distribution of companies by country.

\footnotetext{
11 These countries are: Austria, Belgium, Germany, Denmark, Spain, Finland, France, the United Kingdom, Greece, Ireland, Italy, Luxemburg, Netherlands, Portugal, and Sweden. We select them for our analysis because these were the countries that took the decision of adopting IFRS for consolidated financial statements of listed companies in Europe. Countries entering the EU afterward did not take part on that decision.

${ }^{12}$ Iceland and Liechtenstein are also members of the European Economic Area, but we excluded them from our analysis because of the low number of companies (5 and 1, respectively, in the Global Vantage database before the screening process).

13 The sample includes firms cross-listed in the United States. Since these firms are subject to additional disclosure requirements and SEC enforcement, they could introduce a bias in our study. We thank the referee for raising this point. As a robustness check, we repeat all our analyses after excluding firms that cross-list in the United States, and results remain qualitatively unchanged.
} 
Table 1 shows that the number of companies is unevenly distributed across countries. Whereas French companies represent $21 \%$ of observations, Greek firms represent $5 \%$, and Luxemburg represents just $0.3 \%$ of sample firms. This uneven distribution can be partially attributed to the size of the country and the number of companies incorporated. However, differences arise also because of the "early" adoption of IFRS permitted in several countries (e.g., Austria, Belgium, Denmark, Finland, or Germany). As an example, a large number of German companies were applying IFRS before 2005. Due to the characteristics of our research design, these companies are not included in our sample. This explains the relatively low number of companies from Germany as well as Austria, Belgium, or Denmark in our sample. ${ }^{14}$ Finally, our sample includes also a relatively low number of UKbased firms. This is due to the fact that a large number of firms in the United Kingdom, particularly those quoted in the AIM, continue to use local standards.

Table 1 also lists the countries in which the use of IFRS in legal entity financial statements is (and is not) permitted. ${ }^{15}$ As can be seen, half of the countries in our sample impose some restriction on the use of IFRS and do not allow them in all company statements.

\section{Results}

\subsection{Descriptive statistics and correlations}

Table 2 reports the descriptive statistics for the variables used in our analyses. Panel A presents the descriptive statistics for the subsample of full adopters, while Panel B reports statistics for partial adopters. Panel C shows mean differences between IFRS and local standards accounting measures.

Descriptive statistics show that restatements increase the value of earnings in both subsamples, that is, local standards earnings (NIBE) are lower than earnings restated to IFRS (NIBE R), though differences are larger for firms in the group of partial adopters (i.e., 0.014 versus 0.020 ). Regarding the book value of equity, it slightly decreases (increases) in the group of full (partial) adopters, that is, local standards equity (EQUITY) is higher (lower) than equity restated to IFRS (EQUITY R) for full (partial) adopters, with larger differences for firms in partial-adopter countries (i.e., 0.007 versus 0.044). Overall, descriptive statistics suggest the effect of IFRS adoption is different (larger) in partial adopters than in full adopters. Data in Table 2 suggest that IFRS implementation did not bring about a significant accounting change in full-adopter countries.

Table 3 presents the Spearman correlation coefficients for the variables in our study. Panel A presents the correlation matrix for the subsample of firms in full-adopter countries, while Panel B reports correlation coefficients for firms in partial adopters. Correlation coefficients indicate that local standards and IFRS accounting measures are highly correlated in both subsamples. Coefficients are especially large for the book value of equity

\footnotetext{
${ }^{14}$ Exclusion of early adopters (i.e., firms that were allowed to shift to IFRS prior to 2005) from our sample can potentially introduce a bias in our findings. We thank the editor for raising this point. However, the sensitivity analysis performed (described in detail in Section 4.3) indicates that self-selection is not biasing our results.

${ }^{15}$ Data is taken from the European Commission webpage: http://ec.europa.eu/internal market/accounting/docs/ ias-use-of-options en.pdf.
} 
Table 2

Descriptive statistics.

\begin{tabular}{|c|c|c|c|c|c|c|c|}
\hline & \multirow[t]{2}{*}{ Mean } & \multirow{2}{*}{$\begin{array}{l}\text { Standard } \\
\text { deviation }\end{array}$} & \multirow[t]{2}{*}{ Minimum } & \multirow[t]{2}{*}{ Maximum } & \multicolumn{3}{|c|}{ Percentile } \\
\hline & & & & & 25 & 50 & 75 \\
\hline \multicolumn{8}{|c|}{ Panel A: Full adopters } \\
\hline $\mathrm{MKVL}_{\mathrm{t}}$ & 1.212 & 0.396 & 0.501 & 2.800 & 0.963 & 1.150 & 1.411 \\
\hline $\mathrm{CFO}_{\mathrm{t}+1}$ & 0.127 & 0.177 & -0.825 & 1.249 & 0.048 & 0.107 & 0.196 \\
\hline $\mathrm{NIBE}_{t}$ & 0.056 & 0.126 & -0.667 & 0.733 & 0.023 & 0.066 & 0.108 \\
\hline EQUITY $_{\mathrm{t}}$ & 0.783 & 0.527 & 0.080 & 2.823 & 0.391 & 0.637 & 1.061 \\
\hline NIBE $R_{t}$ & 0.070 & 0.128 & -0.674 & 0.677 & 0.031 & 0.074 & 0.118 \\
\hline EQUITY $R_{t}$ & 0.776 & 0.533 & 0.081 & 3.915 & 0.394 & 0.624 & 1.043 \\
\hline \multicolumn{8}{|c|}{ Panel B: Partial adopters } \\
\hline $\mathrm{MKVL}_{\mathrm{t}}$ & 1.239 & 0.378 & 0.496 & 3.344 & 0.984 & 1.177 & 1.415 \\
\hline $\mathrm{CFO}_{\mathrm{t}+1}$ & 0.132 & 0.216 & -1.163 & 1.887 & 0.038 & 0.104 & 0.192 \\
\hline $\mathrm{NIBE}_{\mathrm{t}}$ & 0.036 & 0.137 & -0.597 & 1.052 & 0.007 & 0.055 & 0.088 \\
\hline EQUITY $_{t}$ & 0.821 & 0.615 & 0.076 & 4.262 & 0.439 & 0.662 & 1.003 \\
\hline NIBE $R_{t}$ & 0.056 & 0.145 & -0.649 & 1.052 & 0.010 & 0.066 & 0.099 \\
\hline EQUITY $R_{t}$ & 0.865 & 0.650 & 0.042 & 4.948 & 0.463 & 0.683 & 1.082 \\
\hline
\end{tabular}

Panel C: Mean differences between IFRS and local standards accounting measures

\begin{tabular}{lllcc}
\hline & NIBE R-NIBE & $(\%)$ & EQUITY R-EQUITY & $(\%)$ \\
\hline Full adopters & 0.014 & 25 & -0.007 & -0.89 \\
Partial adopters & 0.020 & 56 & 0.044 & 5 \\
\hline
\end{tabular}

The sample consists of 366 observations in Panel A and 673 in Panel B. MKLV $\mathrm{t}_{\mathrm{t}}$ is market value of equity at closing date; $\mathrm{CFO}_{\mathrm{t}+1}$ is 2005 net cash flow from operating activities; $\mathrm{NIBE}_{\mathrm{t}}$ is 2004 net income before extraordinary items; EQUITY is 2004 book value of equity; NIBE $R_{t}$ is 2004 net income before extraordinary items restated to IFRS; and EQUITY $R_{t}$ is 2004 book value of equity restated to IFRS. All variables are deflated by beginning-of-period market capitalization.

( $\rho=0.937$ for full adopters and $\rho=0.950$ for partial adopters), which suggests that this measure does not significantly change with the adoption of IFRS. Table 3 also shows that earnings and book value of equity are significantly correlated with the market value of equity and one-year-ahead operating cash flows, both prior to and after restatement to IFRS, with correlation coefficients generally larger for firms in the group of full adopters.

\subsection{Regression analyses}

\subsubsection{Differences in accounting quality prior to 2005}

We start our analyses by comparing the value relevance of accounting measures obtained in full-adopter and partial-adopter countries prior to the implementation of IFRS. By value relevance, we refer to the explanatory power of accounting measures (i.e., earnings and book value of equity) for stock prices. Following prior research (e.g., Barth et al., 2008; Hung \& Subramanyam, 2007), we estimate the following model:

$$
\mathrm{MKVL}_{\mathrm{i}}=\alpha+\beta \mathrm{NIBE}_{\mathrm{i}}+\gamma \mathrm{EQUITY}_{\mathrm{i}}+\varepsilon_{\mathrm{i}}
$$


Table 3

Correlation matrix.

\begin{tabular}{|c|c|c|c|c|c|}
\hline & $\mathrm{MKVL}_{\mathrm{t}}$ & $\mathrm{CFO}_{\mathrm{t}+1}$ & $\mathrm{NIBE}_{\mathrm{t}}$ & EQUITY $_{\mathrm{t}}$ & NIBE $R_{t}$ \\
\hline \multicolumn{6}{|c|}{ Panel A: Full adopters } \\
\hline $\mathrm{CFO}_{\mathrm{t}+1}$ & $\begin{array}{l}-0.029 \\
(0.579)\end{array}$ & & & & \\
\hline $\mathrm{NIBE}_{\mathrm{t}}$ & $\begin{array}{l}0.431 \\
(0.000)\end{array}$ & $\begin{array}{l}0.319 \\
(0.000)\end{array}$ & & & \\
\hline EQUITY $_{\mathrm{t}}$ & $\begin{array}{l}0.293 \\
(0.000)\end{array}$ & $\begin{array}{l}0.307 \\
(0.000)\end{array}$ & $\begin{array}{l}0.326 \\
(0.000)\end{array}$ & & \\
\hline NIBE $R_{t}$ & $\begin{array}{l}0.425 \\
(0.000)\end{array}$ & $\begin{array}{l}0.354 \\
(0.000)\end{array}$ & $\begin{array}{l}0.833 \\
(0.000)\end{array}$ & $\begin{array}{l}0.355 \\
(0.000)\end{array}$ & \\
\hline EQUITY $R_{t}$ & $\begin{array}{l}0.275 \\
(0.000)\end{array}$ & $\begin{array}{l}0.327 \\
(0.000)\end{array}$ & $\begin{array}{l}0.341 \\
(0.000)\end{array}$ & $\begin{array}{l}0.937 \\
(0.000)\end{array}$ & $\begin{array}{l}0.424 \\
(0.000)\end{array}$ \\
\hline \multicolumn{6}{|c|}{ Panel B: Partial adopters } \\
\hline $\mathrm{CFO}_{\mathrm{t}+1}$ & $\begin{array}{l}0.006 \\
(0.876)\end{array}$ & & & & \\
\hline $\mathrm{NIBE}_{\mathrm{t}}$ & $\begin{array}{l}0.450 \\
(0.000)\end{array}$ & $\begin{array}{l}0.304 \\
(0.000)\end{array}$ & & & \\
\hline EQUITY $_{\mathrm{t}}$ & $\begin{array}{l}0.250 \\
(0.000)\end{array}$ & $\begin{array}{l}0.227 \\
(0.000)\end{array}$ & $\begin{array}{l}0.316 \\
(0.000)\end{array}$ & & \\
\hline NIBE $R_{t}$ & $\begin{array}{l}0.422 \\
(0.000)\end{array}$ & $\begin{array}{l}0.313 \\
(0.000)\end{array}$ & $\begin{array}{l}0.838 \\
(0.000)\end{array}$ & $\begin{array}{l}0.222 \\
(0.000)\end{array}$ & \\
\hline EQUITY $R_{t}$ & $\begin{array}{l}0.251 \\
(0.000)\end{array}$ & $\begin{array}{l}0.259 \\
(0.000)\end{array}$ & $\begin{array}{l}0.303 \\
(0.000)\end{array}$ & $\begin{array}{l}0.950 \\
(0.000)\end{array}$ & $\begin{array}{l}0.256 \\
(0.000)\end{array}$ \\
\hline
\end{tabular}

Table reports Spearman correlation coefficients. The sample consists of 366 observations in Panel A and 673 in Panel B. MKLV $\mathrm{t}_{\mathrm{t}}$ market value of equity at closing date; $\mathrm{CFO}_{\mathrm{t}+1}$ is 2005 net cash flow from operating activities; NIBE $_{t}$ is 2004 net income before extraordinary items; EQUITY ${ }_{t}$ is 2004 book value of equity; NIBE $R_{t}$ is 2004 net income before extraordinary items restated to IFRS; and EQUITY $\mathrm{R}_{\mathrm{t}}$ is 2004 book value of equity restated to IFRS. All variables are deflated by beginning-of-period market capitalization.

where MKVL is year-end market value of equity, ${ }^{16}$ NIBE is net income before extraordinary items, ${ }^{17}$ and EQUITY is year-end book value of equity. Accounting measures are those obtained from the application of local standards. All variables refer to the 2004 accounting year, and all of them, the intercept included, are deflated by beginningof-period market value of equity. ${ }^{18}$ The results of these estimations are presented in Table 4, Panel A, under the heading of "Model 1."

Results show that both earnings and book value of equity are significant variables in explaining stock prices in both groups of countries. However, the value for the R-squared suggests that accounting measures derived from the application of local standards have more explanatory power for stock prices in the group of full adopters. To formally test

\footnotetext{
${ }^{16}$ Stock prices are used in these estimations as a proxy for the expectations of market participants about future cash flows. The objective is to test which accounting regime provides measures that are more relevant to investors in valuing the firm (Barth, Beaver, \& Landsman, 2001).This is why we used year-end stock prices.

${ }^{17}$ Since reporting of extraordinary items is not aligned to IFRS in all countries, we repeat all our analyses using net income instead of income before extraordinary items. Results remain qualitatively unchanged.

${ }^{18}$ Checks of robustness of results using other deflators are discussed in the sensitivity analysis section.
} 
whether this is the case, we use the Cramer Z-statistic ${ }^{19}$ (Cramer, 1987). The positive and significant value for this statistic confirms the superiority of accounting measures in the group of full adopters. Therefore, results support Hypothesis H1.

We also estimate the same model for the full sample after adding a dummy (PA) indicating whether the country is or is not a partial adopter and the interaction of this dummy with earnings and equity. Specifically, we estimate the following equation:

$$
\begin{aligned}
\text { MKVL }_{i}= & \alpha+\beta_{1} \text { NIBE }_{i}+\beta_{2} \text { EQUITY }_{i}+\beta_{3} \text { PA }_{i}+\beta_{4} \text { NIBE }_{i} * \text { PA }_{i} \\
& +\beta_{5} \text { EQUITY }_{i} * \mathrm{PA}_{i}+\varepsilon_{i}
\end{aligned}
$$

where PA is a dummy that takes the value of 1 when the country where the firm is domiciled is a partial adopter; it takes the value of 0 , otherwise.

Results of this estimation are presented in Table 4, Panel A, under the heading of "Model 2." When interpreting these results, we must take into account that Model 2 allows coefficients on NIBE and EQUITY to vary depending on whether or not the firm is domiciled in a partial-adopter country. For partial adopters, the coefficient on NIBE is given by $\left(\beta_{1}+\beta_{4}\right)$ and the coefficient on EQUITY is given by $\left(\beta_{2}+\beta_{5}\right)$, while for full adopters, the coefficients are $\beta_{1}$ and $\beta_{2}$, respectively. Table 4 shows that the coefficient of the interaction term NIBE $* \mathrm{PA}$ is not significantly different from 0 , which means that the coefficient on earnings for firms in partial adopters is not significantly different from that for firms in full adopters. ${ }^{20}$ However, significant differences are observed for the book value of equity. The interaction term EQUITY $* \mathrm{PA}$ is negative and statistically significant, indicating that the coefficient on EQUITY is significantly lower for firms in the group of partial adopters. Tests on coefficient restrictions, reported also in Table 4 (Panel A), confirm that, whereas the coefficient on earnings is not statistically different between full and partial adopters, the coefficient on equity is significantly larger in the group of full adopters. Results are consistent with those reported previously and indicate that the role played by equity in explaining stock prices is significantly different in both groups of countries.

In addition to the value relevance of accounting measures, we are interested in comparing the ability of earnings obtained from the application of local standards in full versus partial adopters to predict one-year-ahead operating cash flows. To test whether IFRS accounting numbers have higher ability to explain future cash flows than local standards accounting figures, we estimate the following model:

$$
\mathrm{CFO}_{\mathrm{i}}=\alpha+\beta \mathrm{NIBE}_{\mathrm{i}}+\varepsilon_{\mathrm{i}}
$$

\footnotetext{
${ }_{19}$ Prior research uses the Cramer Z-statistic to test for differences in R-squared measures obtained from different samples (e.g., Harris, Lang, \& Möller, 1994; Lang et al., 2006; Van de Meulen, Gaeremynck, \& Willekens, 2007).

${ }^{20}$ Insignificance of differences between partial and full adopters may be explained by the small role played by earnings in explaining stock prices. In unreported analyses, we drop earnings from Eq. (1) and find that the value for the R-squared is $71.3 \%$ for full adopters and $63.2 \%$ for partial adopters, which means that equity on its own explains almost as much as earnings and equity jointly.
} 
where CFO is one-year-ahead (2005) net cash flow from operating activities and NIBE is net income before extraordinary items for 2004 accounting year. The two variables are deflated by average assets. ${ }^{21}$

Results of the estimation of Eq. (3) are presented in Table 4, Panel B, under the heading of "Model 3." As expected, the coefficient on earnings is positive and highly statistically significant in both groups of countries, thereby indicating that future cash flows are positively related to current earnings. The explanatory power of the model, as measured by the R-squared, is higher for firms in full adopters than for firms in partial adopters. These results suggest that, prior to IFRS endorsement, the ability of earnings to explain future cash flows was higher in full-adopter countries. This is confirmed by the positive and highly statistically significant value of the Cramer Z-statistic. Hence, results are consistent with those presented previously referring to the explanatory power of accounting measures for stock prices and provide additional support for our Hypothesis H1.

In the same way as in the value relevance model, we estimate Eq. (3) for the full sample after adding the dummy PA and the interaction term. Specifically, we estimate the following equation:

$$
\mathrm{CFO}_{\mathrm{i}}=\alpha+\beta_{1} \mathrm{NIBE}_{\mathrm{i}}+\beta_{2} \mathrm{PA}_{\mathrm{i}}+\beta_{3} \mathrm{NIBE}_{\mathrm{i}} * \mathrm{PA}_{\mathrm{i}}+\varepsilon_{\mathrm{i}}
$$

Results, presented in Table 4, Panel B, under the heading of "Model 4," show that the interaction term is negative and statistically significant. Thus, the coefficient on earnings is significantly lower for firms in partial adopters than for firms in full adopters, which is confirmed by the test on coefficient restrictions. Results are consistent with those reported previously and, again, indicate that the role played by accounting numbers in explaining future cash flows is significantly different in full-adopter and partial-adopter countries.

Overall, results show significant differences in accounting quality prior to IFRS adoption between countries permitting and prohibiting the use of IFRS in legal entity financial statements after 2005. More precisely, prior to IFRS implementation, accounting measures had more explanatory power for stock prices and future cash flows in those countries that afterward permitted the use of IFRS throughout all company statements. Consistent with our first hypothesis, results suggest that, in full-adopter countries, accounting systems were already oriented toward the provision of high-quality financial reporting. Such an orientation is not likely to exist in partial-adoption countries, where the observed lower level of accounting quality is suggestive of accounting playing other roles, rather than focusing exclusively on satisfying investors' demands for information.

\subsubsection{Changes in accounting quality resulting from mandatory shift to IFRS}

In this section, we test whether accounting quality changed after IFRS adoption and whether the change was different in partial adopters and full adopters. With this aim, we reestimate Eqs. (1) and (3) using the accounting measures restated to IFRS. The results of these re-estimations are presented in Table 5. In order to facilitate the appreciation of the

${ }^{21}$ In the sensitivity analyses section, we discuss the results obtained using other deflators. 
Table 4

Comparisons between full adopters and partial adopters prior to IFRS adoption.

Panel A: Value relevance of earnings and book value of equity

Model 1: $\mathrm{MKVL}_{\mathrm{i}} \alpha+\beta \mathrm{NIBE}_{\mathrm{i}}+\gamma \mathrm{EQUITY}_{\mathrm{i}}+\varepsilon_{\mathrm{i}}$

Model 2: MKVL $_{\mathrm{i}} \quad \alpha+\beta_{1} \mathrm{NIBE}_{\mathrm{i}}+\beta_{2} \mathrm{EQUITY}_{\mathrm{i}}+\beta_{3} \mathrm{PA}_{\mathrm{i}}+\beta_{4} \mathrm{NIBE}_{\mathrm{i}} * \mathrm{PA}_{\mathrm{i}}+\beta_{5} \mathrm{EQUITY}_{\mathrm{i}} * \mathrm{PA}_{\mathrm{i}}+\varepsilon_{\mathrm{i}}$

\begin{tabular}{|c|c|c|c|}
\hline & \multicolumn{2}{|l|}{ Model 1} & \multirow{2}{*}{$\frac{\text { Model } 2}{\text { Full sample }}$} \\
\hline & Full adopters & Partial adopters & \\
\hline Intercept & $\begin{array}{l}3.119 \\
(3.91)^{* *}\end{array}$ & $\begin{array}{l}0.403 \\
(0.32)\end{array}$ & $\begin{array}{l}1.402 \\
(3.15)^{* *}\end{array}$ \\
\hline NIBE & $\begin{array}{l}1.377 \\
(3.60)^{* *}\end{array}$ & $\begin{array}{l}0.699 \\
(2.37) *\end{array}$ & $\begin{array}{l}1.259 \\
(3.55)^{* *}\end{array}$ \\
\hline EQUITY & $\begin{array}{l}1.001 \\
(17.08) * *\end{array}$ & $\begin{array}{l}0.959 \\
(16.72)^{* *}\end{array}$ & $\begin{array}{l}1.035 \\
(18.80)^{* *}\end{array}$ \\
\hline PA & & & $\begin{array}{l}1.163 \\
(46.82)^{* *}\end{array}$ \\
\hline $\mathrm{NIBE} * \mathrm{PA}$ & & & $\begin{array}{l}-0.357 \\
(-0.96)\end{array}$ \\
\hline EQUITY $*$ PA & & & $\begin{array}{l}-1.027 \\
(-17.31)^{* *}\end{array}$ \\
\hline R-squared & $73.02 \%$ & $63.72 \%$ & $85.70 \%$ \\
\hline Observations & 366 & 673 & 1039 \\
\hline Cramer Z-statistic & 8.147 & & \\
\hline$p$-value & 0.000 & & \\
\hline Tests of coefficient restrictions (Model 2) & & $F$-statistic & $p$-value \\
\hline$\beta_{1} \quad \beta_{1}+\beta_{4}$ & & 0.92 & 0.337 \\
\hline$\beta_{2} \quad \beta_{2}+\beta_{5}$ & & 299 & 0.000 \\
\hline
\end{tabular}

Panel B: Explanatory power of earnings for future cash flows

Model 3: $\mathrm{CFO}_{\mathrm{i}} \quad \alpha+\beta \mathrm{NIBE}_{\mathrm{i}}+\varepsilon_{\mathrm{i}}$

Model 4: $\mathrm{CFO}_{\mathrm{i}} \quad \alpha+\beta_{1} \mathrm{NIBE}_{\mathrm{i}}+\beta_{2} \mathrm{PA}_{\mathrm{i}}+\beta_{3} \mathrm{NIBE}_{\mathrm{i}} * \mathrm{PA}_{\mathrm{i}}+\varepsilon_{\mathrm{i}}$

\begin{tabular}{|c|c|c|c|}
\hline & \multicolumn{2}{|l|}{ Model 3} & \multirow{2}{*}{$\frac{\text { Model } 4}{\text { Full sample }}$} \\
\hline & Full adopters & Partial adopters & \\
\hline Intercept & $\begin{array}{l}0.428 \\
(1.34)\end{array}$ & $\begin{array}{l}1.077 \\
(6.29) * *\end{array}$ & $\begin{array}{l}0.306 \\
(1.78)\end{array}$ \\
\hline NIBE & $\begin{array}{l}0.835 \\
(12.28)^{* *}\end{array}$ & $\begin{array}{l}0.711 \\
(12.75) * *\end{array}$ & $\begin{array}{l}0.840 \\
(12.32)^{* *}\end{array}$ \\
\hline PA & & & $\begin{array}{l}0.052 \\
(14.74) * *\end{array}$ \\
\hline $\mathrm{NIBE} * \mathrm{PA}$ & & & $\begin{array}{l}-0.318 \\
(-3.67)^{* *}\end{array}$ \\
\hline R-squared & $42.62 \%$ & $34.03 \%$ & $48.91 \%$ \\
\hline Observations & 366 & 673 & 1039 \\
\hline Cramer Z-statistic & 12.748 & & \\
\hline$p$-value & 0.000 & & \\
\hline Tests of coefficient restrictions (Model 4) & & $F$-statistic & $p$-value \\
\hline$\beta_{1} \beta_{1}+\beta_{3}$ & & 13.45 & 0.000 \\
\hline
\end{tabular}


Table 5

Comparisons between local standards and IFRS.

Panel A: Value relevance of earnings and book value of equity

$\mathrm{MKVL}_{\mathrm{i}} \quad \alpha+\beta \mathrm{NIBE}_{\mathrm{i}}+\gamma \mathrm{EQUITY}_{\mathrm{i}}+\varepsilon_{\mathrm{i}}$

\begin{tabular}{llllll}
\hline & \multicolumn{2}{l}{ Full adopters } & & & \multicolumn{2}{l}{ Partial adopters } \\
\cline { 2 - 3 } \cline { 5 - 6 } & LS & & & LS & IFRS \\
\hline Intercept & 3.119 & & & & \\
& $(3.91)^{* *}$ & $(3.36)^{* *}$ & & $(0.32)$ & 0.512 \\
NIBE & 1.377 & 1.023 & & 0.699 & $(0.47)$ \\
& $(3.60)^{* *}$ & $(2.72)^{* *}$ & & $(2.37)^{*}$ & 1.302 \\
EQUITY & 1.001 & 0.993 & & 0.959 & $(4.73)^{* *}$ \\
& $(17.08)^{* *}$ & $(14.37)^{* *}$ & & $(16.72)^{* *}$ & 0.862 \\
R-squared & 73.02 & 70.84 & & 63.72 & $(16.52)^{* *}$ \\
Observations & 366 & 366 & & 673 & 65.20 \\
Vuong Z-statistic & 1.28 & & & -1.59 & 673 \\
$p$-value & 0.203 & & & 0.111 &
\end{tabular}

Panel B: Explanatory power of earnings for future cash flows

\begin{tabular}{lllll}
\hline $\mathrm{CFO}_{\mathrm{i}} \alpha+\beta \mathrm{NIBE}_{\mathrm{i}}+\varepsilon_{\mathrm{i}}$ & & & & \\
\hline Intercept & 0.428 & 0.373 & 1.077 & 0.907 \\
& $(1.34)$ & $(1.44)$ & $(6.29)^{* *}$ & $(5.38)^{* *}$ \\
$\mathrm{NIBE}$ & 0.835 & 0.863 & 0.711 & 0.774 \\
& $(12.28)^{* *}$ & $(15.04)^{* *}$ & $(12.75)^{* *}$ & $(14.81)^{* *}$ \\
R-squared & 42.62 & 46.43 & 34.03 & 41.37 \\
Observations & 366 & 366 & 673 & 673 \\
Vuong Z-statistic & -5.32 & & -6.99 & \\
$p$-value & 0.000 & & 0.000 &
\end{tabular}

MKLV is market value of equity at closing date; NIBE is net income before extraordinary items; EQUITY is book value of equity; and CFO is one-year-ahead net cash flow from operating activities. Variables under the headings of LS and IFRS are as originally reported and restated to IFRS, respectively. All variables are deflated by beginningof-period market capitalization in Panel A and by average assets in Panel B. Models are estimated with White's correction for heteroskedasticity. T-statistics are shown in parentheses. The Vuong Z-statistic is used to compare the explanatory power of models for LS versus IFRS.

** Indicate statistical significance at $1 \%$.

* Indicate statistical significance at $5 \%$.

differences motivated by IFRS adoption, Table 5 also reports the results of the estimation of Models 1 and 3, using accounting measures derived from local standards as reported in Table 4.

Notes to Table 4:

MKLV is market value of equity at closing date; NIBE is net income before extraordinary items as originally reported (local standards); EQUITY is book value of equity as originally reported (local standards); CFO is oneyear-ahead net cash flow from operating activities. All variables are deflated by beginning-of-period market capitalization in Panel A and by average assets in Panel B. Models are estimated with White's correction for heteroskedasticity. T-statistics are shown in parentheses. Cramer's Z-statistic compares the explanatory power of models in the group of full adopters versus partial adopters.

** Indicate statistical significance at $1 \%$.

*Indicate statistical significance at $5 \%$. 
Panel A in Table 5 presents the results referring to the explanatory power of accounting measures for stock prices. In the same way as when examining local standards accounting figures, results indicate that earnings and book value of equity under IFRS are significant variables in explaining stock prices. When comparing IFRS and local standards, the value for the R-squared suggests that the explanatory power of accounting measures for stock prices did not change significantly after IFRS adoption. Only a slight decrease (increase) is observed in the subsample of full (partial) adopters. To formally test whether differences are statistically significant, we use the Vuong Z-statistic (Vuong, 1989). This is a directional test, designed to evaluate competing non-nested models, that indicates which model is closer to explaining the data. ${ }^{22}$ The Vuong Z-statistic takes a negative value for the subsample of partial adopters and a positive value for full adopters, thereby suggesting that local standards dominate IFRS in the group of full adopters and IFRS dominate local standards in the group of partial adopters. However, differences are not statistically significant in either case. Descriptive statistics (see Table 2) show little variation in equity after restatement to IFRS. This, in addition to the fact that equity on its own explains most of the variability in stock prices (see footnote 20), can account for the reason why no significant changes in value relevance are observed after IFRS restatement.

We also re-estimate Eq. (3) to investigate whether the explanatory power of accounting measures for future cash flows significantly changes after IFRS adoption. Results are presented in Table 5, Panel B. As expected, the coefficient on earnings is positive and highly statistically significant in both groups of countries. Regarding the comparison of IFRS and local standards, the value for the R-squared indicates that earnings obtained under IFRS have more explanatory power for future cash flows. The value for the Vuong Z-statistic, negative and highly statistically significant in the two groups, confirms that IFRS earnings measures dominate earnings figures obtained from local standards. Furthermore, results show that the change in accounting quality is larger in the group of partial adopters. The R-squared increases $21.6 \%$ in this group, as compared to an increase of $8.9 \%$ in the group of full adopters.

Taken together, the results of the value relevance analysis and the prediction of future cash flows provide modest support for Hypothesis H2. The ability of earnings to explain future cash flow increases significantly after the restatement to IFRS, and the magnitude of the increase is, as expected, larger in the group of partial adopters. However, no significant differences are observed in the explanatory power of accounting measures for stock prices, though the fact that it increases (decreases) in the group of partial (full) adopters suggests that the impact of IFRS in accounting quality is not uniform across these two groups of countries.

\subsubsection{Accounting quality after IFRS adoption}

The last step in our analyses is the comparison of accounting quality between full and partial adopters after IFRS implementation. This requires the comparison of models

\footnotetext{
22 The Vuong Z-statistic is widely used by accounting researchers in discriminating between competing nonnested models (e.g., Dechow, 1994; Barth, Cram, et al., 2001; Al-Attar \& Hussain, 2004).
} 
presented under the headings of "Full adopters-IFRS" and "Partial adopters-IFRS" in Table 5. For purposes of clarity, Table 6 reports again these models, under the headings of "Model 1" and "Model 3," as well as the Cramer Z-statistic used to compare them.

Results show that, despite the fact that the set of accounting standards is the same, there are still important differences in accounting quality between firms in full-adopter and partial-adopter countries. The values for the R-squared indicate that the explanatory power of accounting measures for stock prices and future cash flows is higher for firms in the group of full adopters than for companies in partial adopters. The Cramer Z-statistic confirms that firms in full-adopter countries exhibit a significantly higher level of accounting quality, thus supporting Hypothesis H3.

As we did when we examined accounting quality prior to IFRS adoption, we reestimate IFRS models for the full sample after adding the PA dummy and the corresponding interaction terms. Results of these estimations are presented in Table 6 under the headings of "Model 2" and "Model 4." Results mirror those obtained for local standards measures. In Model 2, we find that the coefficient on earnings is not significantly different for full and partial adopters (i.e., the interaction term is not significantly different from zero), while the coefficient on equity is significantly lower for partial adopters (i.e., the interaction term is negative and significant). These results are confirmed by tests on coefficient restrictions also reported in Table 6. As for Model 4 , the negative and significant coefficient of the interaction term indicates that the coefficient on earnings is significantly lower in the group of partial adopters, as also shown by the test on coefficient restrictions. Results evidence the different role played by accounting measures in explaining stock prices and future cash flows in the groups of full and partial adopters.

Overall, results reported in Table 6 show that after IFRS implementation there are still significant differences in accounting quality between firms in full-adopter and partialadopter countries. Accounting quality, as measured by the explanatory power of accounting measures for stock prices and future cash flows, is still significantly higher for full-adopter countries than for partial-adopter countries after IFRS implementation. These findings are consistent with Hypothesis $\mathrm{H} 3$ and provide further support for the argument that accounting does not play the same role in countries permitting and prohibiting the use of IFRS in legal entity financial statements. Differences in accounting quality after IFRS adoption are indicative of a stronger demand for high-quality financial reporting in those countries permitting the use of IFRS in legal entity financial statements.

Consistent with the findings reported by Ball et al. (2003), we provide additional evidence showing that reporting quality is not only determined by accounting standards, but also by the institutional setting where these standards are applied. In our study, the same set of accounting standards applied in different countries is found to result in significantly different levels of accounting quality. Nonetheless, comparison of accounting quality before and after IFRS adoption (Table 4 versus Table 6) suggest that differences between both groups of countries are substantially lowered (i.e., differences in R-squared drop from 9.3 to 5.6 for the value relevance model and from 8.6 to 5.06 for the cash flow model). Therefore, results suggest that, as expected, the adoption of IFRS is reducing differences in accounting quality across European countries. 
Table 6

Comparisons of full adopters and partial adopters after IFRS adoption.

Panel A: Value relevance of earnings and book value of equity

Model 1: MKVL $_{\mathrm{i}} \alpha+\beta$ NIBE $\mathrm{R}_{\mathrm{i}}+\gamma$ EQUITY $\mathrm{R}_{\mathrm{i}}+\varepsilon_{\mathrm{i}}$

Model 2: MKVL $_{\mathrm{i}} \alpha+\beta_{1} \mathrm{NIBE}_{\mathrm{i}}+\beta_{2}$ EQUITY $\mathrm{R}_{\mathrm{i}}+\beta_{3} \mathrm{PA}_{\mathrm{i}}+\beta_{4}$ NIBE $\mathrm{R}_{\mathrm{i}} * \mathrm{PA}_{\mathrm{i}}+\beta_{5}$ EQUITY $\mathrm{R}_{\mathrm{i}} * \mathrm{PA}_{\mathrm{i}}+\varepsilon_{\mathrm{i}}$

\begin{tabular}{llll}
\hline & Model 1 & & Model 2 \\
\cline { 2 - 4 } & Full adopters & Partial adopters & Full sample \\
\hline Intercept & 2.857 & 0.512 & 1.291 \\
& $(3.36)^{* *}$ & $(0.47)$ & $(3.56)^{* *}$ \\
NIBE R & 1.023 & 1.302 & 0.909 \\
& $(2.72)^{* *}$ & $(4.73)^{* *}$ & $(2.57)^{* *}$ \\
EQUITY R & 0.993 & 0.862 & 1.028 \\
& $(14.37)^{* *}$ & $(16.52)^{* *}$ & $(15.99)^{* *}$ \\
PA & & & 1.138 \\
& & & $(46.18)^{* *}$ \\
NIBE R $*$ PA & & & 0.008 \\
& & & $(0.02)$ \\
EQUITY R*PA & & & -1.010 \\
R-squared & $70.84 \%$ & $65.20 \%$ & $(-15.02)^{* *}$ \\
Observations & 366 & 673 & $85.08 \%$ \\
Cramer Z-statistic & 5.073 & & 1039 \\
$p$-value & 0.000 & & \\
Tests of coefficient restrictions (Model 2) & & $F$-statistic & \\
$\beta_{1} \quad \beta_{1}+\beta_{4}$ & & 0.00 & $p$-value \\
$\beta_{2} \quad \beta_{2}+\beta_{5}$ & & 255 & 0.982 \\
& & & 0.000
\end{tabular}

Panel B: Explanatory power of earnings for future cash flows

Model 3: $\mathrm{CFO}_{\mathrm{i}} \quad \alpha+\beta \mathrm{NIBE} \mathrm{R}_{\mathrm{i}}+\varepsilon_{\mathrm{i}}$

Model 4: $\mathrm{CFO}_{\mathrm{i}} \quad \alpha+\beta_{1} \mathrm{NIBE}_{\mathrm{i}}+\beta_{2} \mathrm{PA}_{\mathrm{i}}+\beta_{3} \mathrm{NIBE} \mathrm{R}_{\mathrm{i}} * \mathrm{PA}_{\mathrm{i}}+\varepsilon_{\mathrm{i}}$

\begin{tabular}{|c|c|c|c|}
\hline & \multicolumn{2}{|l|}{ Model 3} & \multirow{2}{*}{$\frac{\text { Model } 4}{\text { Full sample }}$} \\
\hline & Full adopters & Partial adopters & \\
\hline Intercept & $\begin{array}{l}0.373 \\
(1.44)\end{array}$ & $\begin{array}{l}0.907 \\
(5.38)^{* *}\end{array}$ & $\begin{array}{l}0.262 \\
(1.81)\end{array}$ \\
\hline NIBE $R$ & $\begin{array}{l}0.863 \\
(15.04)^{* *}\end{array}$ & $\begin{array}{l}0.774 \\
(14.81)^{* *}\end{array}$ & $\begin{array}{l}0.867 \\
(15.28)^{* *}\end{array}$ \\
\hline PA & & & $\begin{array}{l}0.046 \\
(13.43)^{* *}\end{array}$ \\
\hline $\mathrm{NIBE} \mathrm{R} * \mathrm{PA}$ & & & $\begin{array}{l}-0.304 \\
(-3.95)^{* *}\end{array}$ \\
\hline R-squared & $46.43 \%$ & $41.37 \%$ & $51.85 \%$ \\
\hline Observations & 366 & 673 & 1039 \\
\hline Cramer Z-statistic & 7.112 & & \\
\hline$p$-value & 0.000 & & \\
\hline Tests of coefficient restrictions (Model 4) & & $F$-statistic & $p$-value \\
\hline$\beta_{1} \quad \beta_{1}+\beta_{3}$ & & 15.59 & 0.000 \\
\hline
\end{tabular}


Table 7

Differences between full adopters and partial adopters.

\begin{tabular}{|c|c|c|c|c|c|c|}
\hline Variable & & Mean & t-statistic & $p$-value & K-Wallis statistic & $p$-value \\
\hline \multirow[t]{2}{*}{ Importance of equity market } & PA & 9.350 & -4.117 & 0.001 & 8.371 & 0.004 \\
\hline & FA & 18.157 & & & & \\
\hline \multirow{2}{*}{ Tax-book conformity } & PA & 1.000 & 5.000 & 0.001 & 5.769 & 0.005 \\
\hline & FA & 0.167 & & & & \\
\hline \multirow[t]{2}{*}{ Sources of GAAP } & PA & 0.000 & -3.041 & 0.010 & 3.429 & 0.064 \\
\hline & FA & 0.571 & & & & \\
\hline \multirow[t]{2}{*}{ Public enforcement } & PA & 0.400 & -0.075 & 0.942 & 0.000 & 1.000 \\
\hline & FA & 0.407 & & & & \\
\hline \multirow[t]{2}{*}{ Liability standard } & PA & 0.324 & -2.372 & 0.034 & 3.646 & 0.056 \\
\hline & FA & 0.584 & & & & \\
\hline
\end{tabular}

Importance of equity market is measured as in Leuz et al. (2003) as the mean rank of three variables used in La Porta, Lopez-de-Silanes, Shleifer, and Vishny (1997): the ratio of the aggregate stock market capitalization held by minorities to gross national product, the number of listed domestic firms relative to the population, and the number of IPOs relative to population. Higher values in each variable indicate greater importance of the equity market. Taxbook conformity is Hung's index of convergence between tax and financial reporting (Hung, 2001). The index takes the value of 1 for countries with high tax-book conformity and the value of 0 , otherwise. Sources of GAAP is a dummy variable that takes the value of 1 for countries where the private sector is involved in the standard-setting process and the value of 0 , otherwise. Public enforcement is the index of public enforcement of securities laws constructed by La Porta et al. (2006). Higher values for this index indicate stronger enforcement. Liability standard is the index of liability standards from La Porta et al. (2006) and indicates to what extent liability standards facilitate private enforcement. Higher values for the index indicate lower procedural difficulty in recovering losses from the issuer and its directors, the distributor, or the accountant in a civil liability case for losses due to misleading financial statements.

\subsection{Further analysis}

In this paper, we hypothesize that countries requiring the use of local standards in legal entity financial statements do so because financial reporting in these countries is more oriented toward the fulfillment of needs, such as regulatory ones, rather than satisfying the information demands of capital providers. Given the orientation of IFRS to the needs of investors and creditors, partial-adopter countries are likely to retain their local standards in legal entity financial statements with the aim of maintaining the regulatory role fulfilled by accounting under local standards, since IFRS accounting cannot play this role. Our evidence is consistent with this hypothesis. We find a significantly higher level of accounting quality for firms in fulladopter countries than for firms in partial adopters, both prior to and after IFRS adoption. Hence, our results are indicative of a stronger orientation of accounting toward the needs of capital providers in the group of full adopters. The lower level of accounting quality observed

Notes to Table 6:

MKLV is market value of equity at closing date; NIBE $\mathrm{R}$ is net income before extraordinary items restated to IFRS; EQUITY R is book value of equity restated to IFRS; and CFO is one-year-ahead net cash flow from operating activities. All variables are deflated by beginning-of-period market capitalization in Panel A and by average assets in Panel B. Models are estimated with White's correction for heteroskedasticity. T-statistics are shown in parentheses. The Cramer-Z statistic compares the explanatory power of models in the group of full adopters versus partial adopters.

**Indicate statistical significance at $1 \%$.

*Indicate statistical significance at $5 \%$. 
for firms in partial adopters suggests that companies have lower incentives to issue highquality financial reporting in these countries, which is likely due to the fact that main capital providers usually have direct access to company information.

In this section, we test whether country characteristics are also indicative of the differences in the orientation of financial information. Specifically, we compare the importance of the equity market, the level of tax-book conformity, the involvement of the private sector in the standard-setting process, the strength of public enforcement, and the degree of difficulty in exercising private enforcement in both groups of countries. These are characteristics that prior research has found to be significantly related to accounting quality (e.g., Hanlon, Maydew, \& Shevlin, 2008; Leuz, Nanda, \& Wysocki, 2003). Table 7 reports t-statistics and K-Wallis statistics used to compare full and partial adopters.

Results show the existence of significant differences between both groups of countries in all the characteristics analyzed, except for public enforcement. Regarding the sources of GAAP, results indicate that the private sector is usually involved in the standard-setting process in full adopters, but not in partial adopters. When accounting rules are set by government bodies (i.e., the private sector is not involved in the standard-setting process), standards tend to be primarily aimed at satisfying regulatory needs, such as computing income taxes, instead of addressing the needs of capital providers (Choi \& Mueller, 1992). Hence, partial adopters are likely to have accounting standards more oriented toward the fulfillment of regulatory needs. The significantly higher degree of financial-tax alignment exhibited by partial adopters also is indicative of the regulatory role (i.e., computation of income taxes) played by accounting in these countries.

Significant differences also are observed regarding the importance of the equity market, which is found to be significantly higher in full adopters than in partial adopters. Results suggest that firms in full adopters depend more on the equity market for their financing than companies in partial adopters. Accordingly, they are likely to face a stronger demand for high-quality financial reporting. On the contrary, companies in partial adopters are likely to get most of their financing from banks or large shareholders, who usually have a direct access to company information. As a consequence, the demand for high-quality accounting is lower. Differences observed for liability standards point to the same conclusion. When trying to recover losses due to misleading financial reporting in a civil liability case, financial statements users face significantly lower procedural difficulty in full-adopter than in partial-adopter countries. Hence, firms are more likely to engage in high-quality financial reporting in full-adopter countries.

Overall, differences in country characteristics are indicative of an orientation of accounting systems toward regulatory needs in those countries prohibiting the use of IFRS in legal entity financial statements. This evidence is consistent with that provided in prior sections and supports our hypothesis that partial adopters retain the use of local standards in legal entity financial statements to ensure that accounting keeps fulfilling the regulatory role it used to play in these countries.

\subsection{Sensitivity analyses}

\subsubsection{Self selection bias}

Companies applying IFRS or U.S. GAAP prior to mandatory IFRS adoption (early adopters) did not enter into our sample because of our research design. As we wanted to 
compare accounting quality prior to and after IFRS adoption holding everything else constant, we formed our sample with those companies that shifted from domestic standards to IFRS in 2005 when application of IFRS became mandatory. Exclusion of early adopters from our sample can potentially introduce a bias in our findings, since early adopters are likely to be firms with the largest incentives to issue high-quality information. Hence, the lower accounting quality observed for firms in the group of partial adopters reported previously could be due to the fact that once early adopters are excluded the remaining firms were those with the lowest incentives to issue high-quality information.

In order to test whether self-selection bias affects our results, we re-estimate our models, including in our sample all companies applying IFRS in 2005, disregarding whether these companies were early adopters. ${ }^{23}$ The sample size increases significantly, particularly in the group of partial adopters, ${ }^{24}$ but results are totally consistent with those obtained for our original sample. Results are reported in Table 8, where it can be observed that the explanatory power of accounting measures for stock prices and future cash flows is significantly higher for firms in the group of full adopters. Hence, we also document significant differences in accounting quality between both groups of countries when early adopters enter into the sample.

As a further robustness check, we re-estimate our models using 2005 IFRS accounting data, instead of the 2004 restated figures to IFRS. Results, untabulated, are totally consistent with those presented in Table 8 .

\subsubsection{Use of other deflators}

Since there is no agreement over the best deflator to be used in order to mitigate scale effects when dealing with levels variables, we follow the recommendation of Barth and Clinch (2005) and test the robustness of our results using different deflators. We start by reestimating Eq. (1), deflating all variables by average assets. Results, untabulated, are totally consistent with those presented in Tables 4-6.

In the same way, we re-estimate Eq. (3) after deflating all variables by net sales and market capitalization at the beginning of the period. The direction of the results, untabulated, is the same as that reported in Tables 4-6. Hence, we are confident that results regarding the ability of earnings to explain stock prices and future cash flows are not sensitive to the use of different deflators.

\subsubsection{Estimation with country fixed effects}

Finally, we also checked the robustness of results of our value relevance models by estimating them with country fixed effects in order to control for differences in market risk across countries. Results, unreported, remain qualitatively unchanged.

\footnotetext{
${ }^{23}$ Since early adopters did not provide financial information under local GAAPs for the 2004 accounting period, our analysis refers exclusively to comparisons of accounting numbers restated to IFRS.

${ }^{24}$ In countries such as Germany, a large number of companies were applying IFRS or U.S. GAAP prior to mandatory IFRS adoption.
} 
Table 8

Comparisons of full adopters and partial adopters after IFRS adoption (sample includes early adopters).

Panel A: Value relevance of earnings and book value of equity

MKVL $_{i} \quad \alpha+\beta$ NIBE $R_{i}+\gamma$ EQUITY $R_{i}+\varepsilon_{i}$

\begin{tabular}{lll}
\hline & Full adopters & Partial adopters \\
\hline Intercept & 0.055 & 1.257 \\
NIBE R & $(0.10)$ & $(1.27)$ \\
& 0.714 & 1.023 \\
EQUITY R & $(2.34)^{*}$ & $(5.03)^{* *}$ \\
& 1.070 & 0.866 \\
R-squared & $(17.35)^{* *}$ & $(19.83)^{* *}$ \\
Observations & $70.79 \%$ & $65.89 \%$ \\
Cramer Z-statistic & 424 & 963 \\
$p$-value & 4.106 &
\end{tabular}

Panel B: Explanatory power of earnings for future cash flows

\begin{tabular}{lll}
\hline $\mathrm{CFO}_{\mathrm{i}} \alpha+\beta \mathrm{NIBE} \mathrm{R}_{\mathrm{i}}+\varepsilon_{\mathrm{i}}$ & & \\
\hline Intercept & 0.392 & 0.796 \\
& $(1.54)$ & $(3.55)^{* *}$ \\
NIBE R & 0.828 & 0.687 \\
& $(16.70)^{* *}$ & $(16.58)^{* *}$ \\
R-squared & $46.83 \%$ & $32.83 \%$ \\
Observations & 424 & 963 \\
Cramer Z-statistic & 19.97 & \\
$p$-value & 0.000 & \\
\hline
\end{tabular}

The sample is comprised of 424 (963) firms applying IFRS in 2005 in the group of full (partial) adopter countries. The sample includes firms that voluntarily shift to IFRS prior to 2005. MKLV is market value of equity at 2004 closing date; NIBE R is 2004 net income before extraordinary items restated to IFRS; EQUITY R is 2004 book value of equity restated to IFRS; and CFO is one-year-ahead (2005) net cash flow from operating activities. All variables are deflated by beginning-of-period market capitalization in Panel A and by average assets in Panel B. Models are estimated with White's correction for heteroskedasticity. T-statistics are shown in parentheses. The Cramer Z-statistic compares the explanatory power of models in the group of full adopters versus partial adopters. $* *$ Indicate statistical significance at $1 \%$.

* Indicate statistical significance at $5 \%$.

\section{Discussion and conclusions}

This study investigates whether the decision made by a number of European countries to retain the use of local standards for legal entity financial statements after IFRS adoption is explained by the orientation of their accounting systems toward the satisfaction of regulatory needs. Specifically, we compare accounting quality between those countries permitting (full adopters) and prohibiting (partial adopters) the use of IFRS in legal entity financial statements both prior to and after IFRS adoption. Accounting quality (i.e., explanatory power of accounting measures for stock prices and future cash flows) is used in this study as an indicator of the orientation of accounting systems toward the needs of capital providers. We find that accounting quality is significantly higher for firms in the group of full adopters, both prior to and after IFRS adoption. We interpret these results as 
evidence that accounting systems are primarily oriented toward the needs of investors and creditors in full-adopter countries but serve other purposes (e.g., computation of income taxes) in partial-adopter countries. Furthermore, since IFRS are designed toward the information needs of capital providers, they may not fulfill regulatory requirements, which still represent a major objective of financial reporting in partial-adopter countries. This can explain why partial adopters decided to retain their local standards for the preparation of legal entity financial statements. By doing so, the information needs of capital providers of listed companies are covered by IFRS consolidated financial statements, while legal entity financial statements, prepared in accordance with local standards, continue to fulfill the regulatory needs.

Additionally, our study contributes to prior research by providing evidence on the differences in accounting quality existing across European countries. Prior research documents the differences in accounting quality across countries soon after the implementation of the European Directives (e.g., Alford, Jones, Leftwich, \& Zmijewski, 1993; Joos \& Lang, 1994). Our study adds to this body of research by showing that significant differences still persisted in 2004, despite the effort taken inside the EU to harmonize accounting. Furthermore, we show that adoption of IFRS reduced these differences, but it did not completely remove them, since accounting quality in 2005 was still significantly higher after IFRS implementation for firms in the group of full adopters. Choices made by firms within IFRS are likely to be affected by firms' incentives to issue high-quality information. As a consequence, firms operating in financial environments where they have lower incentives to produce high-quality financial reporting are likely to choose those alternatives that are more compatible with their local GAAP. Therefore, firms in these countries do not achieve the same level of accounting quality as those operating in the group of full adopters. These results add to prior evidence by showing that the set of accounting standards is not the only factor that shapes accounting quality (Ball et al., 2003). In our study, the same set of accounting standards (IFRS) applied in relatively similar countries (EU Member States) leads to significant differences in accounting quality. Hence, adoption of IFRS by itself is not sufficient to achieve a high level of accounting quality in all countries. Regulation EC 1606/2002 already recognizes that a proper and rigorous enforcement regime is essential to protect investors and improve confidence in capital markets. Acknowledging this, the EU is making important efforts to strengthen IFRS enforcement (by monitoring compliance and taking appropriate measures in cases of infringements). Nonetheless, our results suggest that, even with stricter enforcement, accounting quality may vary across countries because of differences in firms' incentives to issue high-quality information, which are influenced, for example, by their dependence on the equity market for their financing.

\section{References}

Ahearne, A. G., Griever, W. L., \& Warnock, F. E. (2004). Information costs and home bias: An analysis of U.S. holdings of foreign equities. Journal of International Economics, 62, 313-336.

Al-Attar, A., \& Hussain, S. (2004). Corporate data and future cash flows. Journal of Business Finance \& Accounting, 31(7 8), 861-903.

Alford, A., Jones, J., Leftwich, R., \& Zmijewski, M. (1993). The relative informativeness of accounting disclosures in different countries. Journal of Accounting Research, 31, 183-223. 
Ali, A., \& Hwang, L. S. (2000). Country-specific factors related to financial reporting and value relevance of accounting data. Journal of Accounting Research, 38, 1-21.

Armstrong, C., Barth, M. E., Jagolinzer, A. D., \& Riedl, E. J. (2008). Market reaction to the adoption of IFRS in Europe. Working paper 09-032. : Harvard Business School.

Ashbaugh, H. (2001). Non-US firms' accounting standard choices. Journal of Accounting and Public Policy, 20, $129-153$.

Ashbaugh, H., \& Pincus, M. (2001). Domestic accounting standards, international accounting standards, and the predictability of earnings. Journal of Accounting Research, 39, 417-434.

Bae, K. -H., Tan, H., \& Welker, M. (2008). International GAAP differences: The impact on foreign analysts. The Accounting Review, 83(3), 593-628.

Ball, R., Kothari, S. P., \& Robin, A. (2000). The effect of international institutional factors on properties of accounting earnings. Journal of Accounting and Economics, 29, 1-51.

Ball, R., Robin, A., \& Wu, J. S. (2003). Incentives versus standards: Properties of accounting income in four East Asian countries. Journal of Accounting and Economics, 36, 235-270.

Ball, R., \& Shivakumar, L. (2005). Earnings quality in United Kingdom private firms: Comparative loss recognition timeliness. Journal of Accounting and Economics, 39, 83-128.

Barth, M. E., Beaver, W. H., \& Landsman, W. R. (2001). The relevance of the value relevance literature for financial accounting standard setting: Another view. Journal of Accounting and Economics, 31, 77-104.

Barth, M., \& Clinch, G. (2005). Scale effects in capital markets-based accounting research. Working Paper, Stanford University. Available at. www.ssrn.com

Barth, M. E., Cram, D., \& Nelson, K. (2001). Accruals and the prediction of future cash flows. The Accounting Review, 76, 27-58.

Barth, M. E., Landsman, W. R., \& Lang, M. H. (2008). International accounting standards and accounting quality. Journal of Accounting Research, 46(3), 467-498.

Barth, M. E., Landsman, W. R., Lang, M., \& Williams, C. (2009). Are international accounting standards-based and US GAAP-based accounting amounts comparable? Working Paper. Available at. www.ssrn.com

Bartov, E., Goldberg, S., \& Kim, M. (2005). Comparative value relevance among German, U.S. and international accounting standards: A German stock market perspective. Journal of Accounting, Auditing and Finance, 20, 95-119.

Bradshaw, M., Bushee, B., \& Miller, G. (2004). Accounting choice, home bias, and U.S. investment in non-U.S. firms. Journal of Accounting Research, 42(5), 795-841.

Burgstahler, D. C., Hail, L., \& Leuz, C. (2006). The importance of reporting incentives: Earnings management in European private and public firms. The Accounting Review, 81, 983-1016.

Bushman, R. M., \& Piotroski, J. D. (2006). Financial reporting incentives for conservative accounting: The influence of legal and political institutions. Journal of Accounting and Economics, 42, 107-148.

Cañibano, L., \& Mora, A. (2000). Evaluating the statistical significance of de facto accounting harmonization: A study of European global players. European Accounting Review, 9(3), 349-369.

Carmona, S., \& Trombetta, M. (2008). On the global acceptance of IAS/IFRS accounting standards: The logic and implications of the principles-based system. Journal of Accounting and Public Policy, 27, 455-461.

Choi, F. D. S., \& Mueller, G. G. (1992). International accounting. Englewood Cliffs, N.J.: Prentice-Hall.

Christensen, H., Lee, E., \& Walker, M. (2007). Cross-sectional variation in the economic consequences of international accounting harmonization: The case of mandatory IFRS adoption in the United Kingdom. The International Journal of Accounting, 42(4), 341-379.

Christensen, H. B., Lee, E., \& Walker, M. (2008). Incentives or standards: What determines accounting quality changes around IFRS adoption?AAA 2008 Financial Accounting and Reporting Section (FARS) Available at SSRN:. http://ssrn.com/abstract 1013054

Commission Communication COM 95(508) (1995). Accounting harmonisation: A new strategy vis-vis international harmonisation. Commission Communication of 11.1995.

Committee of the European Securities Regulators (CESR) (2007). CESR's review of the implementation and enforcement of IFRS in the EU.

Covrig, V. M., Defond, M. L., \& Hung, M. (2007). Home bias, foreign mutual fund holdings, and the voluntary adoption of international accounting standards. Journal of Accounting Research, 45, 41-70.

Cramer, J. (1987). Mean and variance of $R^{2}$ in small and moderate samples. Journal of Econometrics, 35(2 3), 253-266.

Cuijpers, R., \& Buijink, W. (2005). Voluntary adoption of non-local GAAP in the European Union: A study of determinants and consequences. European Accounting Review, 14, 487-524. 
Daske, H., \& Gebhardt, G. (2006). International financial reporting standards and experts' perceptions of disclosure quality. Abacus, 42(3/4), 461-498.

Daske, H., Hail, L., Leuz, C., \& Verdi, R. (2008). Mandatory IFRS reporting around the world: Early evidence on the economic consequences. Journal of Accounting Research, 46(5), 1085-1142.

Dechow, P. M. (1994). Accounting earnings and cash flows as measures of firm performance: The role of accounting accruals. Journal of Accounting and Economics, 18, 3-42.

Ding, Y., Hope, O. -K., Jeanjean, T., \& Stolowy, H. (2007). Differences between domestic accounting standards and IAS: Measurement determinants and implications. Journal of Accounting and Public Policy, 26, $1-38$.

Ding, Y., Jeanjean, T., \& Stolowy, H. (2005). Why do national GAAP differ from IAS? The role of culture. The International Journal of Accounting, 40, 325-350.

Fama, E., \& French, K. (1993). Common risk factors in the returns on stocks and bonds. Journal of Financial Economics, 33, 3-56.

Gassen, J., \& Sellhorn, T. (2006). Applying IFRS in Germany. Determinants and consequences. Working Paper. Available at. www.ssrn.com

Gómez-Biscarri, J., \& López-Espinosa, G. (2008). Accounting measures and international pricing models: Justifying accounting homogeneity. Journal of Accounting and Public Policy, 27, 339-354.

Hail, L., \& Leuz, C. (2007). Capital market effects of mandatory IFRS reporting in the EU: Empirical evidence. Amsterdam: Netherlands Authority for the Financial Markets Available at:. http:/www.afm.nl/corporate/ default.ashx?DocumentId 10519

Hanlon, M., Maydew, E. L., \& Shevlin, T. (2008). An unintended consequence of book-tax conformity: A loss of earnings informativeness. Journal of Accounting and Economics, 46c, 294-311.

Harris, T., Lang, M., \& Möller, H. P. (1994). The value relevance of German accounting measures: An empirical analysis. Journal of Accounting Research, 32(2), 187-209.

Hope, O. K., Justin, Y., \& Kang, T. (2006). Empirical evidence on jurisdictions that adopt IFRS. Journal of International Accounting Research, 5(2), 1-20.

Hung, M. (2001). Accounting standards and value relevance of financial statements: An international analysis. Journal of Accounting and Economics, 30, 401-420.

Hung, M., \& Subramanyam, K. R. (2007). Financial statement effects of adopting international accounting standards: The case of Germany. Review of Accounting Studies, 12(4), 623-658.

Institute of Chartered Accountants of England and Wales (ICAEW) (2007). EU implementation of IFRS and the fair value directive. A Report for the European Commission, October.

International Organization of Securities Commissions (IOSCO) (2000). A resolution on IASC standards. Presidents' Committee of IOSCO, May.

Jaafar, A., \& McLeay, S. (2007). Country effects and sector effects on the harmonization of accounting policy choice. Abacus, 43(2), 156-189.

Jeanjean, T., \& Stolowy, H. (2008). Do accounting standards matter? An exploratory analysis of earnings management before and after IFRS adoption. Journal of Accounting and Public Policy, 27, 480-494.

Jermakowicz, E., \& Gornik-Tomaszewski, S. (2006). Implementing IFRS from the perspective of EU publicly traded companies. Journal of International Accounting, Auditing and Taxation, 15, 170-196.

Joos, P., \& Lang, M. (1994). The effects of accounting diversity: Evidence from the European Union.Journal of Accounting Research, 32, 141-168 (Supplement).

La Porta, R., Lopez-de-Silanes, F., \& Shleifer, A. (2006). What works in securities laws? The Journal of Finance, 61(1), 1-32.

La Porta, R., Lopez-de-Silanes, F., Shleifer, A., \& Vishny, R. W. (1997). Legal determinants of external finance. Journal of Finance, 52, 1131-1150.

La Porta, R., Lopez-de-Silanes, F., Shleifer, A., \& Vishny, R. W. (1998). Law and finance. The Journal of Political Economy, 106(6), 1113-1155.

Land, J., \& Lang, M. H. (2003). Empirical evidence on the evolution of international earnings. The Accounting Review, 77, 115-133.

Lang, M., Raedy, J. S., \& Wilson, W. (2006). Earnings management and cross listing: Are reconciled earnings comparable to US earnings? Journal of Accounting and Economics, 42, 255-283.

Leuz, C., Nanda, D., \& Wysocki, D. (2003). Earnings management and investor protection: An international comparison. Journal of Accounting and Economics, 69, 505-527. 
Leuz, C., \& Verrechia, R. E. (2000). The economic consequences of increased disclosure.Journal of Accounting Research, 389124.

Nobes, C. W. (1998). Towards a general model of the reasons for international differences in financial reporting. Abacus, 34(2), 162-187.

Nobes, C. W. (Ed.). (2001). GAAP 2001: A survey of national accounting rules benchmarked against international accounting standards. International Forum on Accountancy Development.

Pownall, G., \& Schipper, K. (1999). Implications of accounting research for the SEC's consideration of international accounting standards. Accounting Horizons, 13, 259-280.

Regulation (EC) 1606/2002 of the European Parliament and the Council of 19 July 2002 on the application of International Accounting Standards, Official Journal of the European Communities.

Thorell, P., \& Whittington, G. (1994). The harmonization of accounting within the EU Problems, perspectives and strategies. European Accounting Review, 3(2), 215-240.

Van de Meulen, S., Gaeremynck, A., \& Willekens, M. (2007). Attribute differences between U.S. GAAP and IFRS earnings: An exploratory study. The International Journal of Accounting, 42, 123-142.

Vuong, Q. H. (1989). Likelihood ratio tests for model selection and non-nested hypotheses. Econometrica, 57, 307-333.

Whittington, G. (2005). The adoption of international standards in the European Union. European Accounting Review, 14(1), 127-153. 